\title{
Aberrant Promoter Methylation of YAP Gene and its Subsequent Downregulation in Indian Breast Cancer Patients
}

\author{
Sumayya Abdul Sattar Real', Farah Parveen ${ }^{1}$, Asad Ur Rehman ${ }^{1}$, Mohammad Aasif Khan', \\ Sankaravamasam Venkata Suryanarayan Deo ${ }^{2}$, Nootan Kumar Shukla ${ }^{2}$ and Syed Akhtar Husain ${ }^{1 *}$ (D)
}

\begin{abstract}
Background: YAP, a potent oncogene and major downstream effector of the mammalian Hippo tumor suppressor pathway can act as either oncogene or tumor suppressor gene based on the type of tissue involved. Despite various studies, the role and mechanism through which YAP mediates its tumor suppressor or oncogenic effects are not yet fully understood. Therefore in the present study we aimed to investigate YAP at DNA, mRNA and protein level and also attempted to correlate our molecular findings with various clinicopathological variables of the patients.

Methods: The study comprised of a total 137 genetically unrelated women with sporadic breast cancer cases and normal adjacent tissues not infiltrated with tumor. Mutation of YAP gene was analyzed by automated DNA sequencing. YAP promoter methylation was studied using MS-PCR. Expression at mRNA and protein level was studied using $\mathrm{QPCR}$ and $\mathrm{IHC}$ respectively.

Results: In our study YAP mRNA expression was found to be $8.65 \pm 6.17$ fold downregulated in $67.15 \%$ cases. The expression of YAP when analyzed at the protein level by IHC was found to be absent in $78.83 \%$ cases. Results from MSPCR analysis showed that YAP promoter methylation plays an important role in declining the expression of YAP protein. The absence of YAP protein coincided with $86.60 \%$ methylated cases thereby showing a very strong correlation $(p=0.001)$. We also investigated YAP mutation at the major check point sites in the Hippo pathway and observed no mutation. A significant association was observed on correlating mRNA expression with clinical stages $(p=$ 0.038 ) and protein expression with ER status $(p=0.018)$ among Indian breast cancer patients.

Conclusion: The expression of YAP was found to be downregulated in response to aberrant promoter methylation. The downregulation of YAP are consistent with previous studies suggesting it to have a tumor suppressive role in breast cancer. We did not observe any mutation at the major check point sites in the Hippo pathway.
\end{abstract}

Keywords: Downregulation, Hippo pathway, mRNA, Tumor suppressor gene, YAP

\section{Background}

Breast cancer accounts for $25 \%$ all cancers and is the second most common cancer in the world and the fifth cause of overall cancer mortality. Breast cancer is the most common cancer in women with 883,000 cases in less developed regions and 794,000 cases in more developed regions [1]. Breast cancer involves the interconnection of various signaling pathways [2]. Hippo signaling, an emerging tumor suppressor pathway plays a pivotal

\footnotetext{
* Correspondence: akhtarhusain2000@yahoo.com

${ }^{1}$ Department of Biosciences, Jamia Millia Islamia, New Delhi 110025, India

Full list of author information is available at the end of the article
}

role in the development of mammary gland and breast cancer [3, 4].

YAP (Yes-associated protein) is a potent oncogene present at 11q22 amplicon and major downstream effector of the mammalian Hippo tumor suppressor pathway $[5,6]$. YAP elevates invasion, proliferation, conceal apoptosis, and is adequate for transformation [7]. Cell-to-cell contacts lead to the activation of Hippo pathway which in turn leads to the phosphorylation of YAP at various serine residues including serine 127 by concerted action of LATS and MST, two uptream kinases and is secluded from the nucleus by 14-3-3 proteins thus decreasing the transcriptional activities

(c) The Author(s). 2018 Open Access This article is distributed under the terms of the Creative Commons Attribution 4.0 International License (http://creativecommons.org/licenses/by/4.0/), which permits unrestricted use, distribution, and reproduction in any medium, provided you give appropriate credit to the original author(s) and the source, provide a link to the Creative Commons license, and indicate if changes were made. The Creative Commons Public Domain Dedication waiver (http://creativecommons.org/publicdomain/zero/1.0/) applies to the data made available in this article, unless otherwise stated. 
of the target genes [6, 8]. Overexpression of YAP or its nuclear localization is frequently associated with many human cancers [9]. The tumor suppressor role of YAP is demonstrated in several studies showing its reduced level of expression in human breast cancer [10]. However, in breast cancer it is disputable of YAP being an oncogene or a tumor suppressor gene [11]. YAP can act as either oncogene or tumor suppressor gene based on the type of tissue involved [12].

Long-term existence of cancer cells requires the deregulation of diverse molecular processes [13]. Various genetic and epigenetic events in a single cell collaborated with clonal expansion and selection drives the initiation of breast cancer following its tumor progression. These events disrupt the function of gene in cancer $[14,15]$.

Despite various studies, the role and mechanism through which YAP mediates its tumor suppressor or oncogenic effects are not yet fully understood. To the best of our knowledge the status of YAP in Indian breast cancer patients has not been explored. In this manuscript, we have tried to investigate YAP at DNA, mRNA and protein level. We have also attempted to correlate our molecular findings with various clinicopathological variables of the patients.

\section{Methods}

\section{Ethics statement}

The study was approved by the Institutional Ethical Committee of All India Institute of Medical Sciences (AIIMS), New Delhi and the Institutional Human Ethical Committee of Jamia Millia Islamia, New Delhi. Written informed consent was obtained from all the participants in the study.

\section{Biological specimen collection}

A total of 137 genetically unrelated women with sporadic breast cancer cases were included in the study. Normal adjacent breast tissue not infiltrated with tumor served as control. Inclusion criteria included female breast cancer patients in the age group 20 to 79 years with life expectancy of at least 6 months, histopathological confirmation with primary breast cancer and patients ready to consent and abide by the trial related procedures. Exclusion criteria included in the study were previous exposure to chemotherapy or radiotherapy, patients with multiple cancers or undergoing surgery for the second time and patients with acute myocardial or surgical complications. All the breast cancer cases were recruited from the Department of Surgical Oncology, AIIMS. Various clinicopathological parameters of the patients were collected in detail from their medical records (Table 1).
Table 1 Characteristics of study subjects ( $N=137)$

\begin{tabular}{|c|c|}
\hline Characteristic & Cases (\%) \\
\hline \multicolumn{2}{|l|}{ Age (years) } \\
\hline$\leq 50$ & $78(56.93)$ \\
\hline$>50$ & $59(43.07)$ \\
\hline \multicolumn{2}{|l|}{ Age at menarche } \\
\hline$\leq 12$ & $26(18.98)$ \\
\hline$>12$ & $111(81.02)$ \\
\hline \multicolumn{2}{|c|}{ Menopausal status } \\
\hline Premenopausal & $40(29.20)$ \\
\hline Postmenopausal & $97(70.80)$ \\
\hline \multicolumn{2}{|c|}{ Age at menopause } \\
\hline$\leq 45$ & $33(34.02)$ \\
\hline$>45$ & $64(65.98)$ \\
\hline \multicolumn{2}{|l|}{ ER status } \\
\hline Positive & $81(59.12)$ \\
\hline Negative & $56(40.88)$ \\
\hline \multicolumn{2}{|l|}{ PR status } \\
\hline Positive & $47(34.31)$ \\
\hline Negative & $90(65.69)$ \\
\hline \multicolumn{2}{|l|}{ Her2 status } \\
\hline Positive & $66(48.18)$ \\
\hline Negative & $71(51.82)$ \\
\hline \multicolumn{2}{|c|}{ Molecular subtypes of breast cancer } \\
\hline Luminal A & $46(33.58)$ \\
\hline Luminal B & $38(27.74)$ \\
\hline Her2-enriched & $28(20.44)$ \\
\hline TNBC & $25(18.25)$ \\
\hline \multicolumn{2}{|l|}{ Tumor size } \\
\hline$\leq 5$ & $55(40.15)$ \\
\hline$>5$ & $82(59.85)$ \\
\hline \multicolumn{2}{|c|}{ Lymph node status } \\
\hline Positive & $99(72.26)$ \\
\hline Negative & $38(27.74)$ \\
\hline \multicolumn{2}{|l|}{ Clinical stage } \\
\hline $\mid+\|$ & $45(32.85)$ \\
\hline III+IV & $92(67.15)$ \\
\hline \multicolumn{2}{|l|}{ Histological grade } \\
\hline$|+| \mid$ & $95(69.34)$ \\
\hline III & $42(30.66)$ \\
\hline
\end{tabular}

\section{Genomic DNA extraction}

Genomic DNA was extracted from breast tumor and adjacent normal breast tissue based on the standard phenol-chlorofrom extraction method [16]. The quality and quantity of the isolated DNA was assessed by Nanodrop ND 1000 spectrophotometer (Eppendorf, Germany) and 
further confirmed by gel electrophoresis running on $1 \%$ agarose (Sigma-Aldrich, US) at $100 \mathrm{~mA} /$ volt and stained with $0.5 \mu \mathrm{g} / \mathrm{ml}$ of ethidium bromide. The quality and quantity checkups of extracted DNA are shown in Additional file 1: Table S1. The ratio of absorbance at $260 \mathrm{~nm}$ and 280 $\mathrm{nm}\left(\mathrm{A}_{260} / \mathrm{A}_{280}\right)$ was taken to assess the purity of the DNA. $\sim 1.8$ ratio is accepted pure for DNA.

\section{Automated DNA sequencing}

Exon 1, 2, 8 and 9 of YAP gene harbouring codons for serine 61,109, 127, 164, 397 and lysine 494 was amplified using the following set of primers (Table 2). The PCR products underwent purification and direct sequencing carried out at Scigenome labs, Cochin using both forward and reverse pair of primers. The sequencing was repeated in order to avoid any contamination or PCR artifacts and to stringently confirm the mutation.

\section{The Cancer Genome Atlas (TCGA)}

The TCGA project (http://cancergenome.nih.gov/) constitutes genomic data analysis reservoir that has lead to the mapping of alterations in the genome in more than 11,000 human tumors across 33 types of cancer [17-19]. cBioPortal for Cancer Genomics was used to obtain the data (http://www.cbioportal.org/) [20, 21].

\section{Catalogue of Somatic Mutations in Cancer (COSMIC) Analysis for YAP mutations}

The Catalog of Somatic Mutations in Cancer (COSMIC) database (https://cancer.sanger.ac.uk/cosmic), the largest and most comprehensive asset worldwide used to explore the influence of somatic mutations in human cancer, was executed to analyse the mutations of YAP. Pie charts were generated for overview of distribution and substitutions on the coding strand in breast cancer.

\section{Methylation-specific polymerase chain reaction (MS-PCR)} Bisulfite conversion of isolated genomic DNA was done using EZ DNA Methylation-Gold Kit (Zymo Research, Orange, CA, USA) according to the instructions given by the manufacturer. Two different sets of unmethylated and methylated YAP primers were used to amplify the bisulfite-converted product (Table 2). MethPrimer tool was used to design the primers [22]. One CpG island of $546 \mathrm{bp}$ was found in the YAP promoter region when searched by Methprimer (Fig. 1). Commercially available completely unmethylated and methylated human genomic DNA (Zymo Research, Orange, CA, USA) served respectively for unmethylation and methylation positive control. Nuclease-free water instead of bisulfite-converted DNA served as negative control. $25 \mu \mathrm{l}$ reaction volume PCR

Table 2 Details of primers used in the present study

\begin{tabular}{|c|c|c|c|}
\hline Primer & Primer Sequence & $\begin{array}{l}\text { PCR product } \\
\text { size (base pair) }\end{array}$ & $\begin{array}{l}\text { Annealing } \\
\text { Temperatu-re }\left({ }^{\circ} \mathrm{C}\right)\end{array}$ \\
\hline \multicolumn{4}{|l|}{ Mutation primers } \\
\hline \multirow[t]{2}{*}{ YAP1 exon 1 (serine 61) } & F 5'-AGGCAGAAGCCATGGATC-3' & 338 & 56.6 \\
\hline & R 5'-GGTTACCTGTCGGGAGTG-3' & & \\
\hline \multirow[t]{2}{*}{ YAP1 exon 2 (serine 109 and 127) } & F 5'-GGCTGCAATTAAGCGCTGAC-3' & 292 & 61.5 \\
\hline & R 5'-TGCTGGCAGAGGTACATCATC-3' & & \\
\hline \multirow[t]{2}{*}{ YAP1 exon 2 (serine 164) } & F 5'-CGAGCTCATTCCTCTCCAGC-3' & 236 & 55.5 \\
\hline & R 5'-AGATAACTGTCTCCCACC-3' & & \\
\hline \multirow[t]{2}{*}{ YAP1 exon 8 (serine 397) } & F 5'-TTCAGACATTGCAGGACAGG-3' & 248 & 58.8 \\
\hline & R 5'-CCTGTATCCATCTCATCCACAC-3' & & \\
\hline \multirow[t]{2}{*}{ YAP1 exon 9 (lysine 494) } & F 5'-CTCTGTGTGTTTCCACTAGG-3' & 317 & 57.5 \\
\hline & R 5'-CCGGTGCATGTGTCTCCTTAG-3' & & \\
\hline \multicolumn{4}{|l|}{ Methylation primers } \\
\hline \multirow[t]{2}{*}{ YAP1 methylation } & F 5'-AGTTCGTATAGGCGTTCGTTC-3' & 187 & 57.9 \\
\hline & F 5'-CTTAACTACAAAAAATTCTTCCGCT-3' & & \\
\hline \multirow[t]{2}{*}{ YAP1 unmethylation } & F 5'-AAGTTTGTATAGGTGTTTTGTTTGG-3' & 188 & 57.9 \\
\hline & F 5'-CTTAACTACAAAAAATTCTTCCACT-3' & & \\
\hline \multicolumn{4}{|l|}{ Expression primers } \\
\hline \multirow[t]{2}{*}{ YAP1 } & F 5'-AAGCTGCCCGACTCCTTCTTCAAG-3' & 161 & 64.1 \\
\hline & R 5'-GTCAGTGTCCCAGGAGAAACA-3' & & \\
\hline \multirow[t]{2}{*}{ GAPDH } & F 5'-CACTGCCACCCAGAAGACTG-3' & 150 & 61 \\
\hline & R 5'-ATGCCAGTGAGCTTCCCGTT-3' & & \\
\hline
\end{tabular}




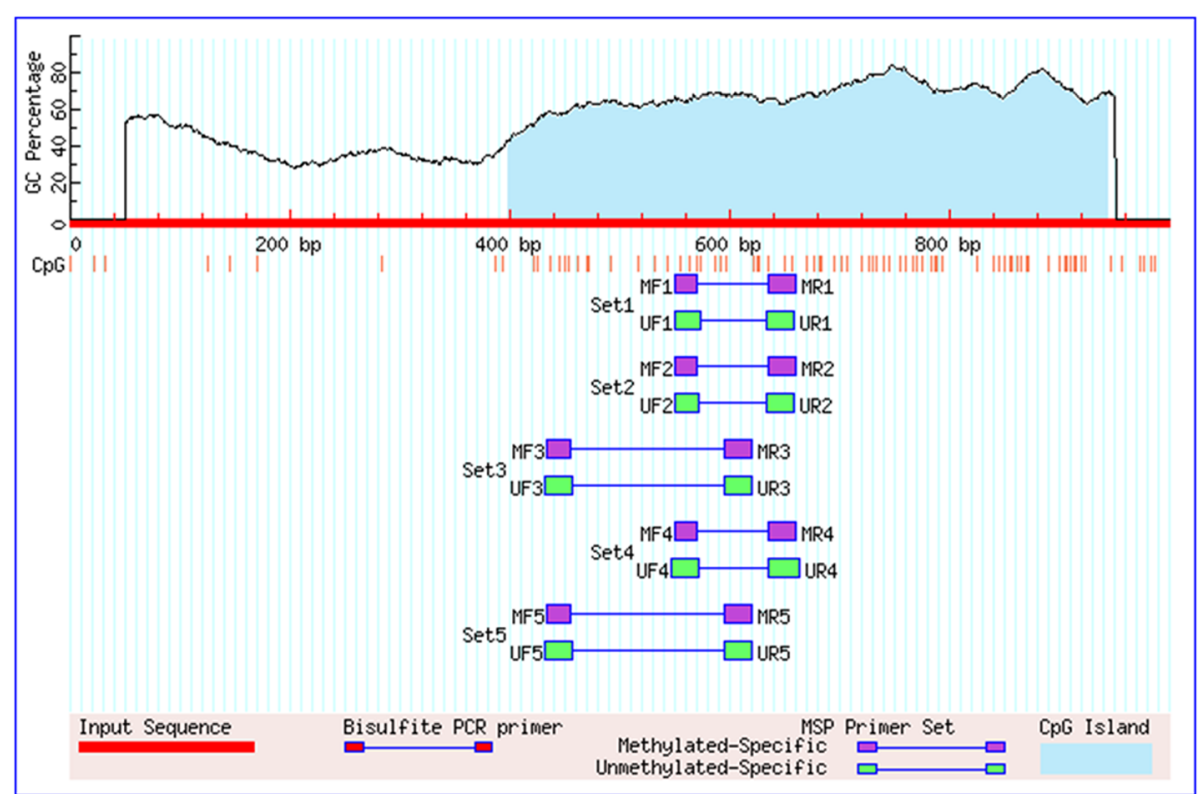

Fig. 1 Graphical representation of CpG islands in the YAP promoter region taken from MethPrimer. Criteria used: Island size > 100, GC Percent > 50.0, Obs/Exp $>0.60$

amplification was performed containing $100 \mathrm{ng}$ of bisulfite-converted DNA, $1.5 \mathrm{mM} \mathrm{MgCl} 2,200 \mu \mathrm{M}$ of each deoxynucleotide triphosphates (dNTPs: dATP, dCTP, dGTP, and dTTP), $0.5 \mu \mathrm{M}$ of each forward and reverse oligonucleotide primers, 1 x PCR buffer, and 1 unit of Hot Start Taq DNA Polymerase (Qiagen, Hilden, Germany). PCR reaction was performed under following conditions : initial denaturation at $95^{\circ} \mathrm{C}$ for $10 \mathrm{~min}$ followed by $35 \mathrm{cy}$ cles with denaturation at $95{ }^{\circ} \mathrm{C}$ for $45 \mathrm{sec}$, annealing at $57.9{ }^{\circ} \mathrm{C}$ for $30 \mathrm{sec}$, and extension at $72{ }^{\circ} \mathrm{C}$ for $45 \mathrm{sec}$, followed by a final extension at $72{ }^{\circ} \mathrm{C}$ for $7 \mathrm{~min} .2 \%$ agarose gel (Sigma-Aldrich, US) containing $0.5 \mu \mathrm{g} / \mathrm{ml}$ of ethidium bromide was run at $100 \mathrm{~mA} /$ volt and the PCR products were visualized, analyzed and photographed under ultraviolet (UV) illumination using Gel Doc (Bio-Rad Laboratories, CA, USA). All the experiments were repeated as an internal quality control and no distortion in the result was observed.

\section{Real-time polymerase chain reaction}

RNA was isolated from the breast tumor and adjacent normal breast tissue stored in the RNA later (Qiagen, Hilden, Germany) by TRIzol Reagent (Invitrogen, CA, USA) according to the instructions given by the manufacturer. Later, the complementary DNA (cDNA) was synthesized using verso cDNA synthesis kit (Thermo Scientific, USA) according to the manufacturer's instruction and was stored at $-20{ }^{\circ} \mathrm{C}$. The quantitative polymerase chain reaction (qPCR) was carried out with LightCycler 96 SYBR Green I Master (Roche Diagnostics India Pvt. Ltd.) using the following set of primers
(Table 2). GAPDH mRNA was used as an internal control, amplified in the same PCR reactions using the following primers (Table 2). PCR amplification were accordingly done : initial denaturation at $95{ }^{\circ} \mathrm{C}$ for $1 \mathrm{~min}$, followed by 35 cycles with denaturation at $94{ }^{\circ} \mathrm{C}$ for $20 \mathrm{sec}$, annealing at $64.1{ }^{\circ} \mathrm{C}$ for $15 \mathrm{sec}$, and extension at $72{ }^{\circ} \mathrm{C}$ for $20 \mathrm{sec}$, followed by a final extension at $72{ }^{\circ} \mathrm{C}$ for $7 \mathrm{~min}$. Quantification were performed in duplicates. Delta delta $\mathrm{Ct}$ method was applied to determine the relative gene expression using qPCR. LightCycler 96 Software 1.5 was used to calculate the relative amount of mRNA as the calibrator normalized ratio which was measured using the formula: $\mathrm{RQ}=2^{-\Delta \Delta \mathrm{Ct}},{ }^{\Delta \Delta \mathrm{Ct}}=\left({ }^{\mathrm{Ct}}\right.$ targeted gene $\left.-{ }^{\mathrm{Ct}} \mathrm{GAPDH}\right)$ targeted sample - $\left({ }^{\mathrm{Ct}}\right.$ targeted gene $\left.-{ }^{\mathrm{Ct}} \mathrm{GAPDH}\right)$ calibration sample. The Ct values for YAP and GAPDH mRNA are shown in Additional file 2: Table S2.

\section{Immunohistochemistry}

Formalin-fixed tissue blocks of breast cancer samples were made which were later sectioned and obtained on poly-L-lysine coated slides. Slides were subjected to deparaffinization through various grades of xylene and rehydrated with ethanol. $0.3 \% \mathrm{H}_{2} \mathrm{O}_{2}$ was used to quench the internal peroxidase activity and antigen retrieval was done by boiling citrate buffer (10 mM; pH 6.0). Serum solution was used as a blocking agent to prevent non-specific interaction, and then the slides were incubated with primary antibody. YAP expression was detected by anti-YAP Mouse monoclonal Antibody (Abcam, UK). Later on, incubation with biotinylated secondary antibody against mouse and streptavidin HRP was performed for 20-30 
min. 3, 3' - diaminobenzidine (DAB) was then added to visualize the antibody binding site followed by counterstaining with hematoxylin. Normal breast tissue served as positive control and sections omitted with primary antibody served as negative control. Staining was evaluated and interpreted by expert histopathologist at 400X magnification under light microscope and graded as: (1) $0 \%$ tumor staining - no expression (2) 1\% - 10\% tumor staining - mild expression (3) $10 \%$ - 50\% tumor staining moderate expression (4) $>50 \%$ tumor staining - high expression.

\section{Statistical analysis}

All the statistical analysis was performed using Statistical Package of Social Science (SPSS, USA) version 17.0 for windows. The data here have been expressed as mean \pm standard deviation (SD). All the comparisons between methylation status, and protein expression with the clinicopathological parameters were performed using Fisher's exact test (two-sided). Wilcoxon signed-ranked test, a non-parametric test was applied to evaluate the significance of differences in mRNA expression levels of YAP/ GAPDH mRNA. All the comparison between mRNA expression and clinicopathological parameters were performed with Kruskal-Wallis test. The $p$ values $<0.05$ were considered to be statistically significant. Each $p$ value was statistically adjusted with Bonferroni correction.

\section{Results}

\section{Downregulated YAP mRNA expression in breast cancer tissue}

YAP mRNA expression was detected at the mRNA level in normal and breast cancer tissues. The expression was normalized against GAPDH expression. YAP mRNA expression was found to be downregulated in $67.15 \%$ cases (92/137), out of which $60.87 \%$ cases $(56 / 92)$ belonged to advanced stages III and IV of breast cancer. The 92 cases that showed downregulation were found to be $8.65 \pm 6.17$ fold downregulated, and the expression at mRNA level of YAP in tumor tissue was $0.11 \pm 5.60$ and in normal tissue was $2.27 \pm 1.65(p=0.0001)$. The mRNA expression when correlated with different clinicopathological parameters of all the patients showed significant association with clinical stage $(p=0.038)$ (Fig. 2 and Table 3). On further analyzing the YAP mRNA expression among different molecular subtype of breast cancer cases, the highest percent downregulation was found in Her-2 enriched (78.57\%) followed by TNBC (76\%), Luminal B (63.16\%), and Luminal A (58.70\%).

\section{YAP protein expression is frequently absent in breast cancer}

The expression of YAP was analyzed at the protein level by IHC and was found to be absent in $78.83 \%(108 / 137)$

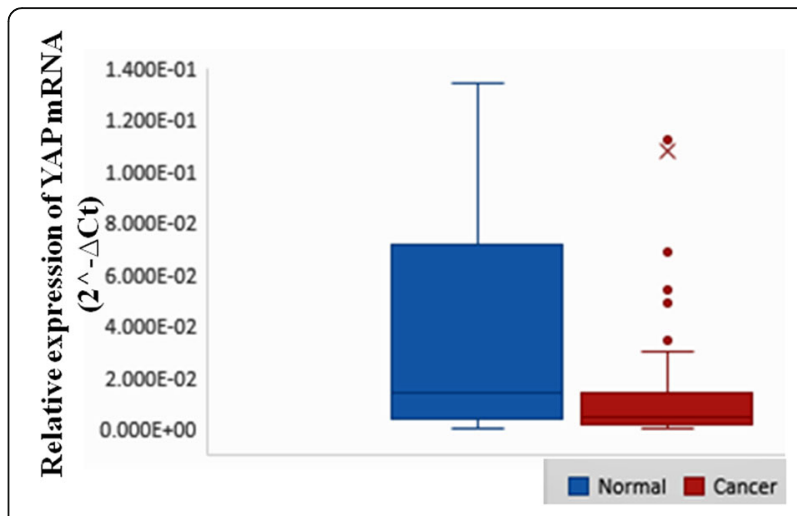

Fig. 2 Box-and-Whisker plots showing relative expression of YAP mRNA in breast cancer and adjacent normal breast tissues. The expression of YAP mRNA in breast cancer cases were significantly lower than normal cases $(p=0.0001)$. The $Y$-axis represents $2 \wedge-\Delta C t$ values for normal and cancer cases. The thick horizontal line in the box indicates the median value (1.389E-02 for normal and 4.518E-03 for cancer), the top and the bottom of the box show the $75^{\text {th }}$ and $25^{\text {th }}$ percentile values and the vertical lines extending from the box represent the largest and smallest values. Mean for normal is 2.268E0 and cancer is $1.076 \mathrm{E}-1$ while Standard deviation for normal is $1.653 \mathrm{E} 1$ and cancer is 5.597E-1

cases. 108 cases had no or very low expression of the protein whereas remaining 29 cases $(21.17 \%)$ cases had moderate to high expression of the protein (Fig. 3 and Table 5) and the percentage of YAP protein downregulation (64.81\%) was higher in advanced stages III and IV of breast cancer. The percentage of YAP protein downregulation in breast cancer subtypes were different to those of YAP mRNA downregulation with 92\% cases downregulation in TNBC followed by Her2-enriched (85.71\%), Luminal B (73.68\%), and Luminal A (71.74\%) (Table 4).

\section{Association between YAP promoter methylation and YAP protein expression in breast cancer}

The methylation status of the YAP promoter was studied through methylation-specific polymerase chain reaction (MS-PCR). The results showed that YAP promoter methylation plays an important role in declining the expression of YAP protein. The absence of YAP protein coincided with $86.60 \%$ (84/97) methylated cases, whereas YAP protein was present in $13.40 \%$ (13/97) methylated cases. Only in $60 \%(24 / 40)$ cases where there was no methylation showed the absence of YAP protein. Further the degree of methylation was $77.78 \%(84 / 108)$ in cases which had downregulation of YAP protein as compared to $44.83 \%(13 / 29)$ cases which had moderate to high protein expression. Therefore, a very strong correlation was observed between YAP promoter methylation and YAP protein expression ( $p=0.001)$ (Fig. 4 and Table 5). 
Table 3 Correlation analysis of YAP1 mRNA expression levels with the clinical parameters in Indian breast cancer patients

\begin{tabular}{|c|c|c|c|}
\hline Characteristic & Total $(N)$ & $\begin{array}{l}\text { YAP1 mRNA expression } \\
\text { relative to GAPDH }\end{array}$ & $p$ value \\
\hline Normal & 137 & $2.27 \pm 1.65$ & 0.0001 \\
\hline Tumor & 137 & $0.11 \pm 5.60$ & \\
\hline \multicolumn{4}{|l|}{ Age (years) } \\
\hline$\leq 50$ & $78(56.93)$ & $0.149 \pm 0.00$ & 0.464 \\
\hline$>50$ & $59(43.07)$ & $0.053 \pm 0.00$ & \\
\hline \multicolumn{4}{|l|}{ Age at menarche } \\
\hline$\leq 12$ & $26(18.98)$ & $0.033 \pm 0.00$ & 0.524 \\
\hline$>12$ & $111(81.02)$ & $0.125 \pm 0.00$ & \\
\hline \multicolumn{4}{|c|}{ Menopausal status } \\
\hline Premenopausal & $40(29.20)$ & $0.036 \pm 0.00$ & 0.462 \\
\hline Postmenopausal & $97(70.80)$ & $0.137 \pm 0.00$ & \\
\hline \multicolumn{4}{|c|}{ Age at menopause } \\
\hline$\leq 45$ & $33(34.02)$ & $0.297 \pm 1.09$ & 0.281 \\
\hline$>45$ & $64(65.98)$ & $0.055 \pm 1.98$ & \\
\hline \multicolumn{4}{|l|}{ ER status } \\
\hline Positive & $81(59.12)$ & $0.121 \pm 0.00$ & 0.373 \\
\hline Negative & $56(40.88)$ & $0.088 \pm 0.00$ & \\
\hline \multicolumn{4}{|l|}{ PR status } \\
\hline Positive & $47(34.31)$ & $0.141 \pm 0.00$ & 0.741 \\
\hline Negative & $90(65.69)$ & $0.090 \pm 0.00$ & \\
\hline \multicolumn{4}{|l|}{ Her2 status } \\
\hline Positive & $66(48.18)$ & $0.053 \pm 0.00$ & 0.506 \\
\hline Negative & $71(51.82)$ & $0.159 \pm 0.00$ & \\
\hline \multicolumn{4}{|c|}{ Molecular subtypes of breast cancer } \\
\hline Luminal A & $46(33.58)$ & $0.149 \pm 0.00$ & 0.731 \\
\hline Luminal B & $38(27.74)$ & $0.079 \pm 0.00$ & \\
\hline Her2-enriched & $28(20.44)$ & $0.018 \pm 0.00$ & \\
\hline TNBC & $25(18.25)$ & $0.178 \pm 0.00$ & \\
\hline \multicolumn{4}{|l|}{ Tumor size } \\
\hline$\leq 5$ & $55(40.15)$ & $0.183 \pm 0.00$ & 0.169 \\
\hline$>5$ & $82(59.85)$ & $0.057 \pm 0.00$ & \\
\hline \multicolumn{4}{|c|}{ Lymph node status } \\
\hline Positive & $99(72.26)$ & $0.109 \pm 0.00$ & 0.203 \\
\hline Negative & $38(27.74)$ & $0.103 \pm 0.00$ & \\
\hline \multicolumn{4}{|l|}{ Clinical stage } \\
\hline $\mid+\|$ & $45(32.85)$ & $0.206 \pm 0.00$ & 0.038 \\
\hline III+IV & $92(67.15)$ & $0.06 \pm 0.00$ & \\
\hline \multicolumn{4}{|l|}{ Histological grade } \\
\hline $\mid+\|$ & $95(69.34)$ & $0.096 \pm 0.00$ & 0.869 \\
\hline III & $42(30.66)$ & $0.135 \pm 0.00$ & \\
\hline
\end{tabular}

$p$ value (Wilcoxon signed-ranked test and Kruskal-Wallis test), Bonferroni significance level $p \leq 0.004$ 


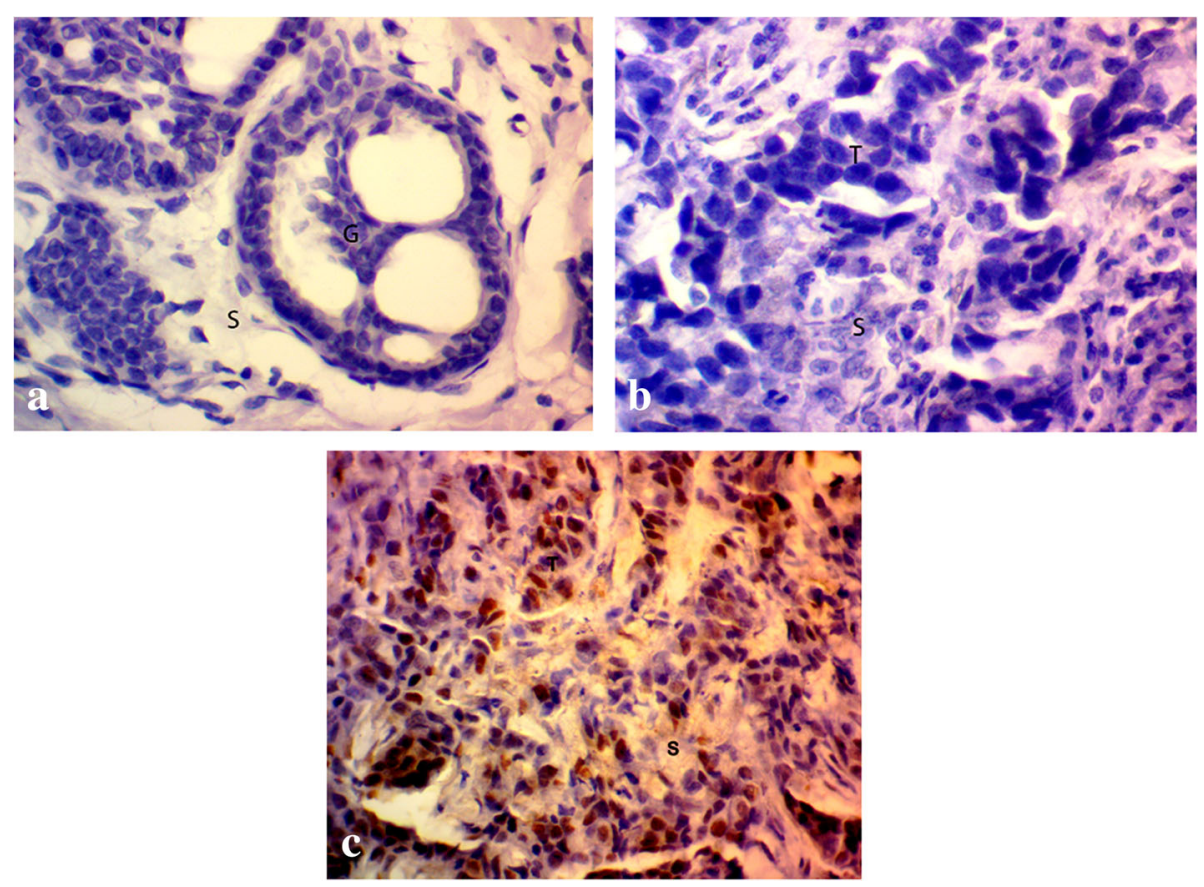

Fig. 3 Immunohistochemical staining of human breast tissue samples by anti-YAP antibody (magnification: 400x) showing (a) normal breast tissue exhibiting negative YAP staining, breast tumor tissue showing (b) absence of YAP expression, and (c) moderate YAP expression. $\mathbf{S}$ stromal tissue, $G$ glandular tissue, $T$ tumor tissue

\section{Association between YAP promoter methylation and clinicopathological parameters in breast cancer}

The promoter methylation when correlated with different clinicopathological parameters of all the patients showed no significant association. In an aggressive stage III and IV of breast cancer around 68.48\% (63/92) cases were found to be methylated (Table 6).

\section{Association between YAP protein expression and clinicopathological parameters in breast cancer} The protein expression when correlated with different clinicopathological parameters of all the patients showed significant association with ER status $(p=0.018)$. Of the 137 cases 92 cases belonged to advanced stage III and IV of breast cancer and 76.09\% (70/92) cases had absence of YAP protein (Table 4). However, 84.13\% (53/63) cases of stage III and IV had no YAP protein expression and had YAP promoter methylation (Table 7).

Correlation between methylation and protein expression of YAP with various clinical characteristics of Indian breast cancer patients showed that more aggressive stage III and IV of breast cancer cases had YAP protein loss significantly correlating with the aberrant YAP promoter methylation $(p=0.016)$ compared to less aggressive stage I and II of breast cancer cases ( $p=$ 0.05). YAP loss in methylated samples was also prevalent in cases having aggressive breast phenotype characteristics with positive lymph node status $(p<0.002)$, larger size of tumor $(p<0.005)$, and PR negative status $(p<0.003)$ (Table 8$)$.

\section{YAP mutation in human breast cancer}

COSMIC database v72 provides over four million variants across various cancer types. COSMIC was used to generate the pie chart which had the information of mutations of substitution nonsense, missense, synonymous, insertion frame shift, and inframe deletion. $57.14 \%$ and $14.29 \%$ were respectively the substitution missense rate and substitution synonymous rate of mutant samples of breast cancer (Additional file 3: Figure S1A). YAP coding strand had 40.00\% $\mathrm{C}>\mathrm{T}$ and $60.0 \% \mathrm{G}>\mathrm{A}$ mutation in breast cancer.

\section{YAP TCGA database in human breast cancer}

Researchers are provided with huge genome and clinical data through web portals and FTP services in TCGA breast cancer database. TCGA database on YAP gene in breast cancer makes available 108 cases affected by 102 mutations across 22 projects. The distribution of the cases is shown in Additional file 3: Figure S1B. The data demonstrates 4 somatic mutations of YAP gene in breast cancer all with low to moderate impact factor.

YAP is not mutated at the major check point sites in the Hippo pathway

No mutation was observed in any of the codons coding for serine 61, 109, 127, 164, 397, and lysine 494. 
Table 4 Correlation analysis of YAP1 protein expression levels with the clinical parameters in Indian breast cancer patients

\begin{tabular}{|c|c|c|c|c|}
\hline Characteristic & Total $(N)$ & YAP1 absent & YAP1 present & $p$ value \\
\hline \multicolumn{5}{|l|}{ Age (years) } \\
\hline$\leq 50$ & $78(56.93)$ & $64(82.05)$ & $14(17.95)$ & \multirow[t]{2}{*}{0.3} \\
\hline$>50$ & $59(43.07)$ & $44(74.58)$ & $15(25.42)$ & \\
\hline \multicolumn{5}{|l|}{ Age at menarche } \\
\hline$\leq 12$ & $26(18.98)$ & $23(88.46)$ & $3(11.54)$ & \multirow[t]{2}{*}{0.258} \\
\hline$>12$ & $111(81.02)$ & $85(76.58)$ & $26(23.42)$ & \\
\hline \multicolumn{5}{|l|}{ Menopausal status } \\
\hline Premenopausal & $40(29.20)$ & $32(80)$ & $8(20)$ & \multirow[t]{2}{*}{1} \\
\hline Postmenopausal & $97(70.80)$ & $76(78.35)$ & $21(21.65)$ & \\
\hline \multicolumn{5}{|l|}{ Age at menopause } \\
\hline$\leq 45$ & $33(34.02)$ & $28(84.85)$ & $5(15.15)$ & \multirow[t]{2}{*}{0.309} \\
\hline$>45$ & $64(65.98)$ & $48(75)$ & $16(25)$ & \\
\hline \multicolumn{5}{|l|}{ ER status } \\
\hline Positive & $81(59.12)$ & $58(71.60)$ & $23(28.4)$ & \multirow[t]{2}{*}{0.018} \\
\hline Negative & $56(40.88)$ & $50(89.29)$ & $6(10.71)$ & \\
\hline \multicolumn{5}{|l|}{ PR status } \\
\hline Positive & $47(34.31)$ & $38(80.85)$ & 9 (19.15) & \multirow[t]{2}{*}{0.826} \\
\hline Negative & $90(65.69)$ & 70 (77.78) & $20(22.22)$ & \\
\hline \multicolumn{5}{|l|}{ Her2 status } \\
\hline Positive & $66(48.18)$ & $52(78.79)$ & $14(21.21)$ & \multirow[t]{2}{*}{1} \\
\hline Negative & $71(51.82)$ & $56(78.87)$ & $15(21.13)$ & \\
\hline \multicolumn{5}{|c|}{ Molecular subtypes of breast cancer } \\
\hline Luminal A & $46(33.58)$ & $33(71.74)$ & $13(28.26)$ & \multirow[t]{4}{*}{0.146} \\
\hline Luminal B & $38(27.74)$ & $28(73.68)$ & $10(26.32)$ & \\
\hline Her2-enriched & $28(20.44)$ & $24(85.71)$ & $4(14.29)$ & \\
\hline TNBC & $25(18.25)$ & $23(92)$ & $2(8)$ & \\
\hline \multicolumn{5}{|l|}{ Tumor size } \\
\hline$\leq 5$ & $55(40.15)$ & $47(85.45)$ & $8(14.55)$ & \multirow[t]{2}{*}{0.139} \\
\hline$>5$ & $82(59.85)$ & $61(74.39)$ & $21(25.61)$ & \\
\hline \multicolumn{5}{|c|}{ Lymph node status } \\
\hline Positive & $99(72.26)$ & $77(77.78)$ & $22(22.22)$ & \multirow[t]{2}{*}{0.816} \\
\hline Negative & $38(27.74)$ & $31(81.58)$ & $7(18.42)$ & \\
\hline \multicolumn{5}{|l|}{ Clinical stage } \\
\hline $\mid+\|$ & $45(32.85)$ & $38(84.44)$ & $7(15.56)$ & \multirow[t]{2}{*}{0.373} \\
\hline III+IV & $92(67.15)$ & $70(76.09)$ & $22(23.91)$ & \\
\hline \multicolumn{5}{|l|}{ Histological grade } \\
\hline $\mid+\|$ & $95(69.34)$ & $76(80)$ & $19(20)$ & \multirow[t]{2}{*}{0.653} \\
\hline III & $42(30.66)$ & $32(76.19)$ & $10(23.81)$ & \\
\hline
\end{tabular}

$p$ value (Fisher's Exact Test), Bonferroni significance level $p \leq 0.005$

\section{Discussion}

The data here demonstrated the downregulation of YAP mRNA expression by $67.15 \%$. The majority of cases $(60.87 \%)$ found to be downregulated belonged to advanced stages III and IV of breast cancer and showed a significant correlation $(p=0.038)$ with clinical stage of breast cancer. At the protein level, YAP was found to be downregulated in $78.83 \%$ cases of breast cancer and these cases had either no or very low expression of YAP protein. A possible explanation for difference in YAP mRNA and protein expression can be due to varied post-transcriptional 


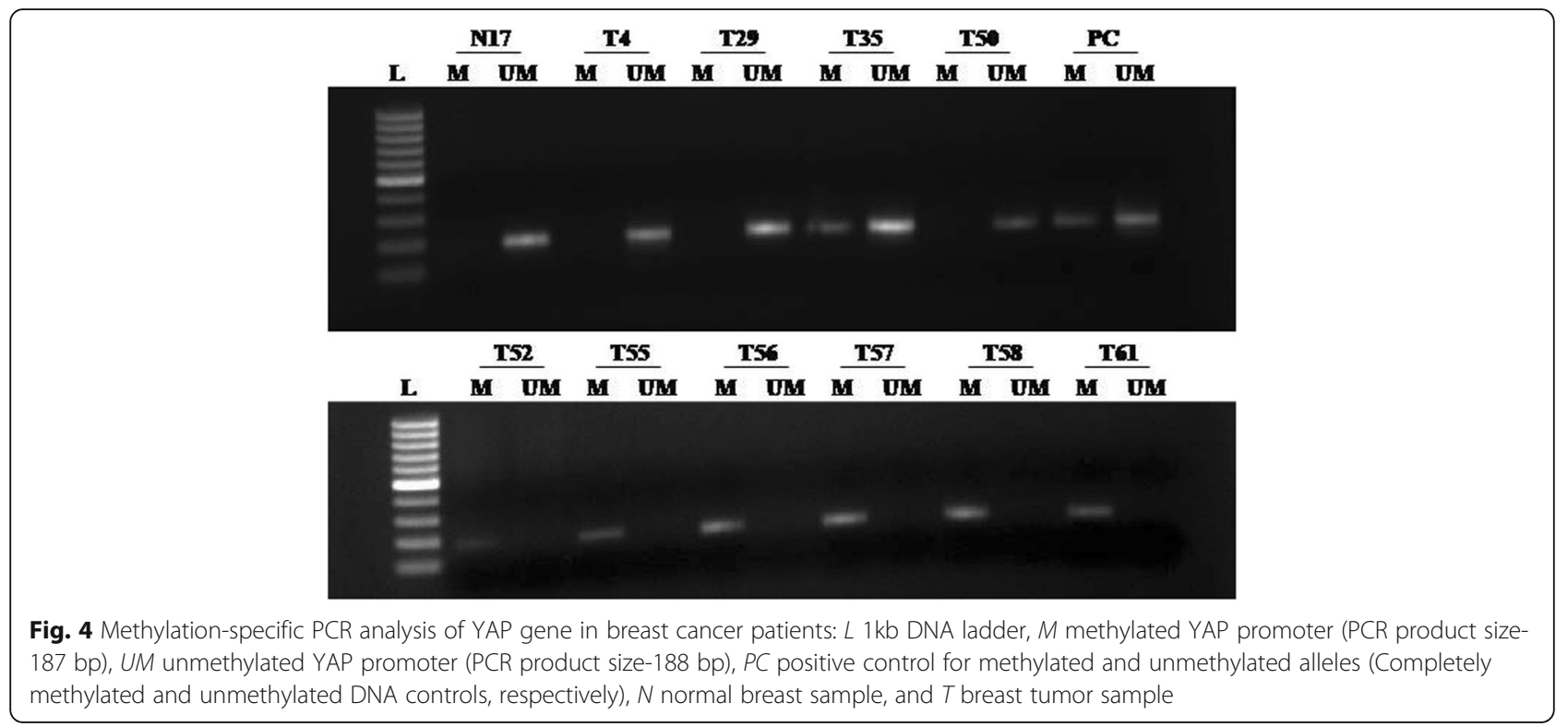

or post-translational modifications or silencing, half lives of mRNA and protein, or due to presence of significant error and noise in mRNA and protein experiments [23-25]. We also observed absence of YAP protein in normal breast tissues. It may be due to the pathological process which also affects histologically normal adjacent breast tissue apart from tumor tissue.

As consistent with YAP mRNA result the percentage of YAP protein downregulation $(64.81 \%)$ was higher in advanced stages III and IV of breast cancer. The downregulation of YAP are consistent with previous studies suggesting it to have a tumor suppressive role in breast cancer $[10-12,26]$. As reported earlier, in response to DNA-damage YAP mediates its tumor suppressor role by binding to p73, a family member p53 and increases p73 ability to induce apoptosis by activating apoptotic pathway [27].
Molecular subtypes of breast cancer showed different degree of YAP protein downregulation highest being TNBC followed by Her2-enriched, Luminal B, and Luminal A. This data is also consistent with earlier study indicating YAP to express differentially according to molecular subtype of cancer [5, 28]. However, we got different percent of downregulation in various subtypes of breast cancer compared to previous study [28]. On correlating the YAP protein expression with various clinicopathological parameters of Indian breast cancer cases we found a significant association with ER status $(p=0.018)$. On further analysis we found YAP to be absent for $89.29 \%$ in ER negative compared to $71.60 \%$ in ER positive. These observations are consistent with the previous study that loss of YAP is associated with ER negativity and that YAP may be a transcriptional coactivator of ER [10, 29]. While no such association was found among YAP expression

Table 5 Correlation analysis of YAP1 promoter methylation with protein expression in Indian breast cancer patients

\begin{tabular}{|c|c|c|c|c|c|}
\hline \multirow[t]{2}{*}{ YAP1 protein expression } & \multicolumn{2}{|l|}{ YAP Promoter } & \multirow[b]{2}{*}{ Total } & \multirow[b]{2}{*}{$p$ value } & \multirow[b]{2}{*}{ OR $(95 \% \mathrm{Cl})$} \\
\hline & $\begin{array}{l}\text { Methylated } \\
\text { (\% within Protein expression) }\end{array}$ & $\begin{array}{l}\text { Unmethylated } \\
\text { (\% within Protein expression) }\end{array}$ & & & \\
\hline Present & $13(44.83 \%)$ & $16(55.17 \%)$ & & & \\
\hline Absent & $84(77.78 \%)$ & $24(22.22 \%)$ & & & \\
\hline Total (\%) & 97 (70.80\%) & $40(29.20 \%)$ & 137 & 0.001 & $0.232(0.098-0.549)$ \\
\hline \multirow[t]{2}{*}{ YAP Promoter } & YAP1 protein expression & & & & \\
\hline & Present & Absent & & & \\
\hline $\begin{array}{l}\text { Methylated } \\
\text { (\% within methylation status) }\end{array}$ & $13(13.4 \%)$ & $84(86.6 \%)$ & & & \\
\hline $\begin{array}{l}\text { Unmethylated } \\
\text { (\% within unmethylation status) }\end{array}$ & $16(40.0 \%)$ & $24(60.0 \%)$ & & & \\
\hline Total (\%) & $29(21.17 \%)$ & $108(78.13 \%)$ & 137 & & \\
\hline
\end{tabular}

$p$ value $p \leq 0.005$ is considered significant 
Table 6 Correlation analysis of YAP1 promoter methylation with the clinical parameters in Indian breast cancer patients

\begin{tabular}{|c|c|c|c|c|}
\hline Characteristics & Cases (\%) & Unmethylated (\%) & Methylated (\%) & $p$ value \\
\hline \multicolumn{5}{|l|}{ Age (years) } \\
\hline$\leq 50$ & $78(56.93)$ & $21(26.92)$ & $57(73.08)$ & \multirow[t]{2}{*}{0.571} \\
\hline$>50$ & $59(43.07)$ & $19(32.20)$ & $40(67.80)$ & \\
\hline \multicolumn{5}{|l|}{ Age at menarche } \\
\hline$\leq 12$ & $26(18.98)$ & $8(30.77)$ & $18(69.23)$ & \multirow[t]{2}{*}{0.815} \\
\hline$>12$ & $111(81.02)$ & $32(28.83)$ & $79(71.17)$ & \\
\hline \multicolumn{5}{|l|}{ Menopausal status } \\
\hline Premenopausal & $40(29.20)$ & $12(30)$ & $28(70)$ & \multirow[t]{2}{*}{1} \\
\hline Postmenopausal & $97(70.80)$ & $28(28.87)$ & $69(71.13)$ & \\
\hline \multicolumn{5}{|l|}{ Age at menopause } \\
\hline$\leq 45$ & $33(34.02)$ & $12(36.36)$ & $21(63.64)$ & \multirow[t]{2}{*}{0.249} \\
\hline$>45$ & $64(65.98)$ & $16(25)$ & $48(75)$ & \\
\hline \multicolumn{5}{|l|}{ ER status } \\
\hline Positive & $81(59.12)$ & 27 (33.33) & $54(66.67)$ & \multirow[t]{2}{*}{0.252} \\
\hline Negative & $56(40.88)$ & $13(23.21)$ & $43(76.79)$ & \\
\hline \multicolumn{5}{|l|}{ PR status } \\
\hline Positive & $47(34.31)$ & $12(25.53)$ & $35(74.47)$ & \multirow[t]{2}{*}{0.556} \\
\hline Negative & $90(65.69)$ & $28(31.11)$ & $62(68.89)$ & \\
\hline \multicolumn{5}{|l|}{ Her2 status } \\
\hline Positive & $66(48.18)$ & $18(27.27)$ & $48(72.73)$ & \multirow[t]{2}{*}{0.708} \\
\hline Negative & $71(51.82)$ & $22(30.99)$ & $49(69.01)$ & \\
\hline \multicolumn{5}{|c|}{ Molecular subtypes of breast cancer } \\
\hline Luminal A & $46(33.58)$ & $16(34.78)$ & $30(65.22)$ & \multirow[t]{4}{*}{0.584} \\
\hline Luminal B & $38(27.74)$ & $12(31.58)$ & $26(68.42)$ & \\
\hline Her2-enriched & $28(20.44)$ & $6(21.43)$ & $22(78.57)$ & \\
\hline TNBC & $25(18.25)$ & $6(24)$ & $19(76)$ & \\
\hline \multicolumn{5}{|l|}{ Tumor size } \\
\hline$\leq 5$ & $55(40.15)$ & $15(27.27)$ & $40(72.73)$ & \multirow[t]{2}{*}{0.707} \\
\hline$>5$ & $82(59.85)$ & $25(30.49)$ & $57(69.51)$ & \\
\hline \multicolumn{5}{|c|}{ Lymph node status } \\
\hline Positive & $99(72.26)$ & $29(29.29)$ & $70(70.71)$ & \multirow[t]{2}{*}{1} \\
\hline Negative & $38(27.74)$ & $11(28.95)$ & $27(71.05)$ & \\
\hline \multicolumn{5}{|l|}{ Clinical stage } \\
\hline $\mid+\|$ & $45(32.85)$ & $11(24.44)$ & $34(75.56)$ & \multirow[t]{2}{*}{0.43} \\
\hline III+IV & $92(67.15)$ & $29(31.52)$ & $63(68.48)$ & \\
\hline \multicolumn{5}{|l|}{ Histological grade } \\
\hline $\mid+\|$ & $95(69.34)$ & $27(28.42)$ & $68(71.58)$ & \multirow[t]{2}{*}{0.839} \\
\hline III & $42(30.66)$ & $13(30.95)$ & $29(69.05)$ & \\
\hline
\end{tabular}

$p$ value (Fisher's Exact Test), Bonferroni significance level $p \leq 0.005$

and PR status as reported earlier [10]. These may be due to differential expression among diverse population.

Gene expression, genetic stability, and genomic structure may be altered by aberrant DNA methylation that can lead to carcinogenesis and tumor progression [30]. Promoter hypermethylation of critical growth regulators like tumor suppressor genes and its subsequent transcription silencing plays a pivitol role in causing cancer [31]. A recent study demonstrated hypomethylation of YAP promoter promotes the expression of YAP in polycystic ovary syndrome [32]. However, methylation status of YAP promoter in breast cancer is not yet known. Our 
Table 7 Correlation analysis of methylation and protein expression in samples having methylated YAP1 promoter or YAP1 expression loss with the clinical parameters in Indian breast cancer patients

\begin{tabular}{|c|c|c|c|c|c|c|c|c|}
\hline \multirow[t]{2}{*}{ Characteristic } & \multirow{2}{*}{$\begin{array}{l}\text { Total } \\
(\mathrm{N})\end{array}$} & \multicolumn{2}{|c|}{ Methylated YAP1 } & \multirow[t]{2}{*}{$p$ value } & \multirow{2}{*}{$\begin{array}{l}\text { Total } \\
(\mathrm{N})\end{array}$} & \multicolumn{2}{|l|}{ YAP1 loss } & \multirow[t]{2}{*}{$p$ value } \\
\hline & & YAP1 Absent & YAP1 Present & & & Unmethylated YAP1 & Methylated YAP1 & \\
\hline \multicolumn{9}{|l|}{ Age (years) } \\
\hline$\leq 50$ & 57 & 50 & 7 & 0.767 & 64 & 14 & 50 & 1 \\
\hline$>50$ & 40 & 34 & 6 & & 44 & 10 & 34 & \\
\hline \multicolumn{9}{|l|}{ Age at menarche } \\
\hline$\leq 12$ & 18 & 17 & 1 & 0.451 & 23 & 6 & 17 & 0.585 \\
\hline$>12$ & 79 & 67 & 12 & & 85 & 18 & 67 & \\
\hline \multicolumn{9}{|c|}{ Menopausal status } \\
\hline Premenopausal & 28 & 23 & 5 & 0.512 & 32 & 9 & 23 & 0.447 \\
\hline Postmenopausal & 69 & 61 & 8 & & 76 & 15 & 61 & \\
\hline \multicolumn{9}{|c|}{ Age at menopause } \\
\hline$\leq 45$ & 21 & 21 & 0 & 0.095 & 28 & 7 & 21 & 0.388 \\
\hline$>45$ & 48 & 40 & 8 & & 48 & 8 & 40 & \\
\hline \multicolumn{9}{|l|}{ ER status } \\
\hline Positive & 54 & 45 & 9 & 0.375 & 58 & 13 & 45 & 1 \\
\hline Negative & 43 & 39 & 4 & & 50 & 11 & 39 & \\
\hline \multicolumn{9}{|l|}{ PR status } \\
\hline Positive & 35 & 30 & 5 & 1 & 38 & 8 & 30 & 1 \\
\hline Negative & 62 & 54 & 8 & & 70 & 16 & 54 & \\
\hline \multicolumn{9}{|l|}{ Her2 status } \\
\hline Positive & 48 & 42 & 6 & 1 & 52 & 10 & 42 & 0.497 \\
\hline Negative & 49 & 42 & 7 & & 56 & 14 & 42 & \\
\hline \multicolumn{9}{|c|}{ Molecular subtypes of breast cancer } \\
\hline Luminal A & 30 & 25 & 5 & 0.837 & 33 & 8 & 25 & 0.87 \\
\hline Luminal B & 26 & 22 & 4 & & 28 & 6 & 22 & \\
\hline Her2-enriched & 22 & 20 & 2 & & 24 & 4 & 20 & \\
\hline TNBC & 19 & 17 & 2 & & 23 & 6 & 17 & \\
\hline \multicolumn{9}{|l|}{ Tumor size } \\
\hline$\leq 5$ & 40 & 36 & 4 & 0.549 & 47 & 11 & 36 & 0.819 \\
\hline$>5$ & 57 & 48 & 9 & & 61 & 13 & 48 & \\
\hline \multicolumn{9}{|c|}{ Lymph node status } \\
\hline Positive & 70 & 61 & 9 & 0.751 & 77 & 16 & 61 & 0.613 \\
\hline Negative & 27 & 23 & 4 & & 31 & 8 & 23 & \\
\hline \multicolumn{9}{|l|}{ Clinical stage } \\
\hline$|+| \mid$ & 34 & 31 & 3 & 0.533 & 38 & 7 & 31 & 0.629 \\
\hline $\mid I I+I V$ & 63 & 53 & 10 & & 70 & 17 & 53 & \\
\hline \multicolumn{9}{|l|}{ Histological grade } \\
\hline $\mid+\|$ & 68 & 59 & 9 & 1 & 76 & 17 & 59 & 1 \\
\hline III & 29 & 25 & 4 & & 32 & 7 & 25 & \\
\hline
\end{tabular}

$p$ value (Fisher's Exact Test), Bonferroni significance level $p \leq 0.0025$

study determines a considerable role of YAP promoter methylation in declining the expression of YAP protein. We got $70.80 \%$ (97/137) methylated breast cancer cases out of which 84 cases had absence of YAP protein thereby showing significantly high correlation $(p=$ 0.001). The remaining 13 methylated cases showed the 
Table 8 Correlation analysis between methylation and protein expression of YAP1 in stratification by various clinical characteristics in Indian breast cancer patients

\begin{tabular}{|c|c|c|c|c|c|c|c|c|c|c|c|}
\hline \multicolumn{6}{|c|}{ charactenstics in inalan breast cancer p } & \multicolumn{6}{|c|}{ naracteristics in indian breast cancer patients (continuea) } \\
\hline \multirow[t]{2}{*}{ Characteristic } & \multirow[t]{2}{*}{ Total $(N)$} & \multirow{2}{*}{$\begin{array}{l}\text { YAP1 } \\
\text { methylation } \\
\text { status }\end{array}$} & \multicolumn{2}{|c|}{ YAP1 expression } & \multirow[t]{2}{*}{$p$ value } & \multirow[t]{2}{*}{ Characteristic } & \multirow[t]{2}{*}{ Total $(N)$} & \multirow{2}{*}{$\begin{array}{l}\text { YAP1 } \\
\text { methylation } \\
\text { status }\end{array}$} & \multicolumn{2}{|c|}{ YAP1 expression } & \multirow[t]{2}{*}{$p$ value } \\
\hline & & & Absent & Present & & & & & Absent & Present & \\
\hline \multicolumn{6}{|l|}{ Age (years) } & Her2-enriched & $28(20.44)$ & M & 20 & 2 & 0.191 \\
\hline \multirow[t]{2}{*}{$\leq 50$} & 78 (56.93) & M & 50 & 7 & 0.046 & & & UM & 4 & 2 & \\
\hline & & UM & 14 & 7 & & TNBC & $25(18.25)$ & M & 17 & 2 & 1 \\
\hline \multirow[t]{2}{*}{$>50$} & $59(43.07)$ & M & 34 & 6 & 0.017 & & & UM & 6 & 0 & \\
\hline & & UM & 10 & 9 & & Tumor size & & & & & \\
\hline \multicolumn{3}{|l|}{ Age at menarche } & & & & $\leq 5$ & $55(40.15)$ & M & 36 & 4 & 0.193 \\
\hline \multirow[t]{2}{*}{$\leq 12$} & $26(18.98)$ & M & 17 & 1 & 0.215 & & & UM & 11 & 4 & \\
\hline & & UM & 6 & 2 & & $>5$ & $82(59.85)$ & M & 48 & 9 & $<0.005$ \\
\hline \multirow[t]{2}{*}{$>12$} & $111(81.02)$ & M & 67 & 12 & 0.002 & & & UM & 13 & 12 & \\
\hline & & UM & 18 & 14 & & Lymph node sta & & & & & \\
\hline \multicolumn{3}{|l|}{ Menopausal status } & & & & Positive & $99(72.26)$ & M & 61 & 9 & $<0.002$ \\
\hline \multirow[t]{2}{*}{ Premenopausal } & $40(29.20)$ & M & 23 & 5 & 0.677 & & & UM & 16 & 13 & \\
\hline & & UM & 9 & 3 & & Negative & $38(27.74)$ & M & 23 & 4 & 0.39 \\
\hline \multirow[t]{2}{*}{ Postmenopausal } & $97(70.80)$ & M & 61 & 8 & $<0.0007$ & & & UM & 8 & 3 & \\
\hline & & UM & 15 & 13 & & Clinical stage & & & & & \\
\hline \multicolumn{3}{|l|}{ Age at menopause } & & & & $\mid+\|$ & $45(32.85)$ & M & 31 & 3 & 0.05 \\
\hline \multirow[t]{2}{*}{$\leq 45$} & $33(34.02)$ & M & 21 & 0 & 0.003 & & & UM & 7 & 4 & \\
\hline & & UM & 7 & 5 & & III+IV & $92(67.15)$ & M & 53 & 10 & 0.016 \\
\hline \multirow[t]{2}{*}{$>45$} & $64(65.98)$ & M & 40 & 8 & 0.016 & & & UM & 17 & 12 & \\
\hline & & UM & 8 & 8 & & Histological grac & & & & & \\
\hline \multicolumn{3}{|l|}{ ER status } & & & & $\mid+\|$ & $95(69.34)$ & M & 59 & 9 & 0.02 \\
\hline \multirow[t]{2}{*}{ Positive } & $81(59.12)$ & M & 45 & 9 & $<0.002$ & & & UM & 17 & 10 & \\
\hline & & UM & 13 & 14 & & III & $42(30.66)$ & M & 25 & 4 & 0.05 \\
\hline \multirow[t]{2}{*}{ Negative } & $56(40.88)$ & M & 39 & 4 & 0.615 & & & UM & 7 & 6 & \\
\hline & & UM & 11 & 2 & & & & & & & \\
\hline
\end{tabular}

PR status

\begin{tabular}{|c|c|c|c|}
\hline \multirow[t]{2}{*}{ Positive } & \multirow[t]{2}{*}{$47(34.31)$} & $M$ & 30 \\
\hline & & UM & 8 \\
\hline \multirow[t]{2}{*}{ Negative } & \multirow[t]{2}{*}{$90(65.69)$} & $M$ & 54 \\
\hline & & UM & 16 \\
\hline
\end{tabular}

Her2 status

$\begin{array}{llllll}\text { Positive } & 66(48.18) & \text { M } & 42 & 6 & 0.014 \\ & & \text { UM } & 10 & 8 & \\ \text { Negative } & 71(51.82) & \text { M } & 42 & 7 & 0.057 \\ & & \text { UM } & 14 & 8 & \end{array}$

Molecular subtypes of breast cancer

$\begin{array}{lllll}\text { Luminal A } & 46(33.58) & \text { M } & 25 & 5 \\ & & \text { UM } & 8 & 8 \\ \text { Luminal B } & 38(27.74) & \text { M } & 22 & 4 \\ & & \text { UM } & 6 & 6\end{array}$

Table 8 Correlation analysis between methylation and protein expression of YAP1 in stratification by various clinical characteristics in Indian breast cancer patients (Continued)

expression of YAP protein. A possible explanation to these results can be due to incomplete promoter methylation and that for methylation to silence a particular gene it should attain certain level of methylation to cross the protective boundary and once achieved the loss of transcription is stable [33]. The presence of unmethylated bands along with methylated bands in MS-PCR in tumor samples could also be explained by the above phenomena. This band may be also due to contamination of normal cells in the tumor samples. Contrary, only $60 \%(24 / 40)$ cases which were unmethylated for YAP promoter showed the loss of YAP protein, suggesting methylation to contribute only partially to protein loss and other molecular mechanism like genetic mutation, genomic deletions, certain transcriptional and post-transcriptional silencing, and post-translational modifications may contribute to YAP protein loss. We found no significant association when YAP promoter 
methylation was correlated with various clinicopathological parameters of Indian breast cancer cases.

Further analysis showed that $84.13 \%$ cases of advanced breast cancer stages III and IV had YAP promoter methylation and subsequent protein loss. Correlating methylation and protein expression of YAP with various clinicopathological characteristics of Indian breast cancer patients showed a significant association with advanced stage III and IV of breast cancer $(p=0.016)$. Majority of cases with YAP loss in methylated samples showed significance with aggressive breast cancer characteristics like lymph node status, larger size of tumor, and PR negative status $(p<0.005)$.

We evaluated the functional effect of the COSMIC mutations considering the possibility of YAP mutation to be oncogenic. Using YAP as a model gene to cross-examine the findings of COSMIC and TCGA, we report that even genes with mutations of known oncogenic functions do not necessarily contribute to growth advantage or other hallmarks of driver gene aetiology.

Studies have shown that LATS1 phosphorylates YAP at multiple sites including serine 61, 109, 127, 164, and 397 thereby inhibiting its nuclear translocation [6,34, 35]. It was also demonstrated that mutations of all the phosphorylation sites abolishes the phosphorylation of YAP by LATS1 [28, 29]. Monomethylation of YAP at lysine 494 demonstrates a methylation dependent checkpoint in the Hippo pathway through cytoplasmic retention. Mutation at this site does not retain YAP cytoplasmically [36]. Based on all these observations we tried to check the mutation of YAP gene in exon 1, 2, 8, and 9 which had codons coding for serine $61,109,127,164,397$, and lysine 494 . We did not observe any mutation in the codons coding these residues. These results suggest that mutation at these sites may not be involved in the development and progression of breast cancer. However, further studies in larger sample size and in different populations are required to confirm the role of mutations at these sites.

As reported in literature, the function of YAP on being a tumor suppressor or oncogene remains controversial. In many solid tumors YAP promotes tumor growth, followed by its progression and metastasis [37]. Hippo pathway is inactivated by any changes in the tissue microenvironment or stimulation of cell by intracellular or extracellular signals thereby hyperactivating YAP. The hyperactivated YAP enters nucleus and interacts with DNA-binding transcription factors like TEA domain/ Transcription Enhancer Factor (TEAD) family, p63/p73, ErbB, Smad, and RUNX1/2 [38, 39]. TEAD, a key transcription factor in hippo pathway acting downstream from YAP is required for the gene expression, cell growth, epithelial to mesenchymal transition, anchorage-independent growth, and oncogenic transformation of YAP [11, 37, 39]. YAP binds to TEAD family of transcription factors and stimulates the downstream transcription of anti-apoptotic and proliferative genes; thereby promoting oncogenesis [39]. Although several studies have demonstrated YAP to be an oncogene our data and results from other studies $[10-12,26,38]$ supports its role to be tumor suppressor.

\section{Conclusion}

To conclude, the role of YAP gene in breast cancer is still controversial. The location of YAP 11q22 is frequently associated with loss of heterozygosity (LOH) [26]. Several studies have shown decreased expression of YAP protein in breast cancer using immunohistochemistry [10, 26-28]. As revealed by $\mathrm{LOH}$ analysis, the loss of protein correlates with specific deletion of YAP gene locus [26]. Furthermore, YAP being coactivators of ER and PR receptors in breast cancer YAP negativity correlates with ER negativity [10]. The observations from all these studies and our results support YAP to be a tumor suppressor gene. Further large-scale study on different population is required to characterize the role of YAP in breast cancer. To the best of our knowledge we are the first to report aberrant promoter methylation of YAP and significant association with its downregulation in Indian breast cancer patients. We are also the first to report the absence of mutation at the major check point sites of YAP gene in Indian breast cancer cases.

\section{Additional files}

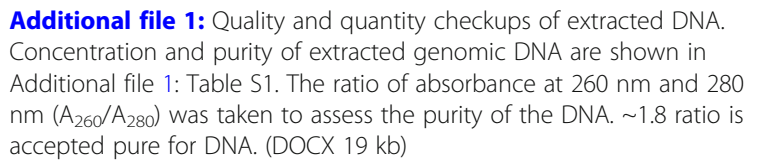

Additional file 2: $\mathrm{Ct}$ values of YAP and GAPDH mRNA. The $\mathrm{Ct}$ values for YAP and GAPDH mRNA for breast cancer cases and adjacent normal breast tissues used as control are shown in Additional file 2: Table S2. YAP mRNA expression was detected at the mRNA level in breast tumor and adjacent normal breast tissue using Real-time PCR. The expression was normalized against GAPDH expression. (DOCX $18 \mathrm{~kb}$ )

Additional file 3: YAP mutation in human breast cancer. TCGA and COSMIC database performed to analyse the mutations of YAP are shown in Additional file 3: Figure S1. The pie chart showing the information of mutations was generated using COSMIC databse. The data obtained using the cBioPortal for Cancer Genomics are shown in 108 cases affected by 102 mutations across 22 projects according to TCGA database. (TIF $4332 \mathrm{~kb}$ )

\section{Abbreviations}

ER: Estrogen receptor; HER-2: Human epidermal growth factor receptor 2; IHC: Immunohistochemistry; PR: Progesterone receptor; TNBC: Triple-negative breast cancer; YAP: Yes-associated protein

\section{Acknowledgements}

The authors thank Dr. Ashok Mukherjee for his assistance and guidance with $\Vdash H C$.

\section{Funding}

This work was supported by University Grant Commission (UGC), Delhi, India [F1-17.1/2015-16/MANF-2015-17-GUJ-65323/(SA-III/Website)]. The funding body had no role in the design of study, collection, analysis, and interpretation of data or preparation of manuscript. 


\section{Availability of data and materials}

All the data generated or analyzed during this study are included in this published article.

\section{Authors' contributions}

S A H: designed and quided the study, R S A S: performed the experiment and wrote the manuscript, F P: drafted and critically revised the manuscript and gave final approval of the version to be published, $A \cup$ R: helped in statistical analysis and interpretation of data, M A K: helped with experiments and acquisition of data, N K S: co-supervisor, provided samples, and helped in analysis of clinical data, S V S D: co-supervisor, provided the samples, and helped in analysis of clinical data. All authors have read and approved the final manuscript.

\section{Ethics approval and consent to participate}

The study was approved by the Institutional Ethical Committee of All India Institute of Medical Sciences (AllMS), New Delhi (Ref. No. IESC/T-455/ 26.08.2015, RT-26/27.01.2016) and the Institutional Human Ethical Committee of Jamia Millia Islamia, New Delhi. All the subjects participating in the study gave their written informed consent.

\section{Consent for publication}

Not applicable.

\section{Competing interests}

The authors declare that they have no competing interests.

\section{Publisher's Note}

Springer Nature remains neutral with regard to jurisdictional claims in published maps and institutional affiliations.

\section{Author details}

'Department of Biosciences, Jamia Millia Islamia, New Delhi 110025, India. ${ }^{2}$ Department of Surgical Oncology, All India Institute of Medical Science, New Delhi 110608, India.

\section{Received: 7 December 2017 Accepted: 21 June 2018} Published online: 03 July 2018

\section{References}

1. Ferlay J, Soerjomataram I, Dikshit R, Eser S, Mathers C, Rebelo M, Parkin DM, Forman D, Bray F. Cancer incidence and mortality worldwide: sources, methods and major patterns in GLOBOCAN 2012. Int J Cancer. 2015;136(5): E359-86.

2. Eroles P, Bosch A, Perez-Fidalgo JA, Lluch A. Molecular biology in breast cancer: intrinsic subtypes and signaling pathways. Cancer Treat Rev. 2012; 38(6):698-707

3. Shi P, Feng J, Chen C. Hippo pathway in mammary gland development and breast cancer. Acta Biochim Biophys Sin (Shanghai). 2015;47(1):53-9.

4. Maugeri-Sacca M, Barba M, Pizzuti L, Vici P, Di Lauro L, Dattilo R, Vitale I, Bartucci M, Mottolese M, De Maria R. The Hippo transducers TAZ and YAP in breast cancer: oncogenic activities and clinical implications. Expert Rev Mol Med. 2015;17:e14.

5. Kim SK, Jung WH, Koo JS. Yes-associated protein (YAP) is differentially expressed in tumor and stroma according to the molecular subtype of breast cancer. Int J Clin Exp Pathol. 2014;7(6):3224-34.

6. Sudol M, Shields DC, Faroog A. Structures of YAP protein domains revea promising targets for development of new cancer drugs. Semin Cell Dev Biol. 2012;23(7):827-33.

7. Overholtzer M, Zhang J, Smolen GA, Muir B, Li W, Sgroi DC, Deng CX, Brugge JS, Haber DA. Transforming properties of YAP, a candidate oncogene on the chromosome 11q22 amplicon. Proc Natl Acad Sci USA. 2006:103(33):12405-10.

8. Basu S, Totty NF, Irwin MS, Sudol M, Downward J. Akt phosphorylates the Yes-associated protein, YAP, to induce interaction with 14-3-3 and attenuation of p73-mediated apoptosis. Mol Cell. 2003;11(1):11-23.

9. Steinhardt AA, Gayyed MF, Klein AP, Dong J, Maitra A, Pan D, Montgomery EA, Anders RA. Expression of Yes-associated protein in common solid tumors. Hum Pathol. 2008;39(11):1582-9.

10. Tufail R, Jorda M, Zhao W, Reis I, Nawaz Z. Loss of Yes-associated protein (YAP) expression is associated with estrogen and progesterone receptors negativity in invasive breast carcinomas. Breast Cancer Res Treat. 2012; 131(3):743-50.

11. Lamar JM, Stern P, Liu H, Schindler JW, Jiang ZG, Hynes RO. The Hippo pathway target, YAP, promotes metastasis through its TEAD-interaction domain. Proc Natl Acad Sci USA. 2012;109(37):E2441-50.

12. Wang H, Du YC, Zhou XJ, Liu H, Tang SC. The dual functions of YAP-1 to promote and inhibit cell growth in human malignancy. Cancer Metastasis Rev. 2014;33(1):173-81.

13. Hergovich A. Mammalian Hippo signalling: a kinase network regulated by protein-protein interactions. Biochem Soc Trans. 2012;40(1):124-8.

14. Polyak K. Breast cancer: origins and evolution. J Clin Invest. 2007; 117(11):3155-63.

15. Baylin SB, Esteller M, Rountree MR, Bachman KE, Schuebel K, Herman JG. Aberrant patterns of DNA methylation, chromatin formation and gene expression in cancer. Hum Mol Genet. 2001;10(7):687-92.

16. Sambrook JR, Russel DW. DW 2001. In: Molecular Cloning: A Laboratory Manual; 2001.

17. Network CGA. Comprehensive molecular portraits of human breast tumours. Nature. 2012;490:61-70.

18. Chin L, Andersen JN, Futreal PA. Cancer genomics: from discovery science to personalized medicine. Nat Med. 2011;17(3):297-303.

19. Tomczak K, Czerwinska P, Wiznerowicz M. The Cancer Genome Atlas (TCGA): an immeasurable source of knowledge. Contemp Oncol (Pozn). 2015;19(1A):A68-77.

20. Gao J, Aksoy BA, Dogrusoz U, Dresdner G, Gross B, Sumer SO, Sun Y, Jacobsen A, Sinha R, Larsson E et al: Integrative analysis of complex cancer genomics and clinical profiles using the cBioPortal. Sci Signal. 2013; 6(269):pl1.

21. Cerami E, Gao J, Dogrusoz U, Gross BE, Sumer SO, Aksoy BA, Jacobsen A, Byrne CJ, Heuer ML, Larsson E, et al. The cBio cancer genomics portal: an open platform for exploring multidimensional cancer genomics data. Cancer Discov. 2012;2(5):401-4.

22. Li LC, Dahiya R. MethPrimer: designing primers for methylation PCRs. Bioinformatics. 2002;18(11):1427-31.

23. Greenbaum D, Colangelo C, Williams K, Gerstein M. Comparing protein abundance and mRNA expression levels on a genomic scale. Genome Biol. 2003;4(9):117.

24. Baldi $\mathrm{P}$, Long $\mathrm{AD}$. A Bayesian framework for the analysis of microarray expression data: regularized $t$-test and statistical inferences of gene changes. Bioinformatics. 2001;17(6):509-19.

25. Szallasi Z. Genetic network analysis in light of massively parallel biological data acquisition. Pac Symp Biocomput. 1999:5-16.

26. Yuan M, Tomlinson V, Lara R, Holliday D, Chelala C, Harada T, Gangeswaran R, Manson-Bishop C, Smith P, Danovi SA, et al. Yesassociated protein (YAP) functions as a tumor suppressor in breast. Cell Death Differ. 2008;15(11):1752-9.

27. Strano S, Munarriz E, Rossi M, Castagnoli L, Shaul Y, Sacchi A, Oren M, Sudol M, Cesareni G, Blandino G. Physical interaction with Yes-associated protein enhances p73 transcriptional activity. J Biol Chem. 2001;276(18):15164-73.

28. Jaramillo-Rodriguez Y, Cerda-Flores RM, Ruiz-Ramos R, Lopez-Marquez FC, Calderon-Garciduenas AL. YAP expression in normal and neoplastic breast tissue: an immunohistochemical study. Arch Med Res. 2014;45(3):223-8.

29. Dhananjayan SC, Ramamoorthy S, Khan OY, Ismail A, Sun J, Slingerland J, O'Malley BW, Nawaz Z. WW domain binding protein-2, an E6-associated protein interacting protein, acts as a coactivator of estrogen and progesterone receptors. Mol Endocrinol. 2006;20(10):2343-54.

30. Wu L, Shen Y, Peng X, Zhang S, Wang M, Xu G, Zheng X, Wang J, Lu C. Aberrant promoter methylation of cancer-related genes in human breast cancer. Oncol Lett. 2016;12(6):5145-55.

31. Baylin SB. DNA methylation and gene silencing in cancer. Nat Clin Pract Oncol. 2005:2(Suppl 1):S4-11.

32. Jiang LL, Xie JK, Cui JQ, Wei D, Yin BL, Zhang YN, Chen YH, Han X, Wang Q, Zhang CL. Promoter methylation of yes-associated protein (YAP) gene in polycystic ovary syndrome. Medicine (Baltimore). 2017;96(2):e5768.

33. Turker MS. Gene silencing in mammalian cells and the spread of DNA methylation. Oncogene. 2002;21(35):5388-93.

34. Hao Y, Chun A, Cheung K, Rashidi B, Yang X. Tumor suppressor LATS1 is a negative regulator of oncogene YAP. J Biol Chem. 2008;283(9):5496-509.

35. Oka T, Mazack V, Sudol M. Mst2 and Lats kinases regulate apoptotic function of Yes kinase-associated protein (YAP). J Biol Chem. 2008; 283(41):27534-46

36. Oudhoff MJ, Freeman SA, Couzens AL, Antignano F, Kuznetsova E, Min PH, Northrop JP, Lehnertz B, Barsyte-Lovejoy D, Vedadi M, Arrowsmith CH, 
Nishina H, Gold MR, Rossi FM, Gingras AC, Zaph C. Control of the hippo pathway by Set7-dependent methylation of Yap. Dev Cell. 2013;26(2):188-94.

37. Andrade D, Mehta M, Griffith J, Panneerselvam J, Srivastava A, Kim TD, Janknecht R, Herman T, Ramesh R, Munshi A. YAP1 inhibition radiosensitizes triple negative breast cancer cells by targeting the DNA damage response and cell survival pathways. Oncotarget. 2017;8(58):98495-508.

38. Ou C, Sun Z, Li S, Li G, Li X, Ma J. Dual roles of yes-associated protein (YAP) in colorectal cancer. Oncotarget. 2017;8(43):75727-41.

39. Zhao B, Ye X, Yu J, Li L, Li W, Li S, Lin JD, Wang CY, Chinnaiyan AM, Lai ZC et al. TEAD mediates YAP-dependent gene induction and growth control. Genes Dev. 2008;22(14):1962-71.

Ready to submit your research? Choose BMC and benefit from:

- fast, convenient online submission

- thorough peer review by experienced researchers in your field

- rapid publication on acceptance

- support for research data, including large and complex data types

- gold Open Access which fosters wider collaboration and increased citations

- maximum visibility for your research: over $100 \mathrm{M}$ website views per year 